\title{
Comparative analysis of two injection systems fueled with biodiesel
}

\begin{abstract}
The paper presents experimental results concerning the fueling of two injection systems for D.I. Diesel engines with Biodiesel fuels. The neat Biodiesel (B100) was obtained from waste vegetable oil (collected from a local branch of McDonald's), using the base catalyzed method; diesel fuel was also used in order to test the injection equipments and obtain reference values. The fuel injection pumps used during the tests were RO-PES4A90D410RS2240 (romanian) and a Bosch type one (PES5MW55/320/RS/120403), with the corresponding high pressure fuel lines and injectors. The injection equipment was mounted on a MIRKOZ test bed, equipped with pressure transducers, rotation angle transducer and a BOSCH injection rate meter. The tests were developed at different pump speeds and displacements of the injection pump control rack. The following injection characteristics were investigated: cyclic fuel delivery, injection duration, pressure wave propagation time, average injection rate, peak injection pressure. For the both types of injection equipment, cyclic fuel delivery, injection duration and peak injection pressure increased when biodiesel was used as fuel (compared to Diesel fuel), while the average injection rate and pressure wave propagation time decreased.
\end{abstract}

Key words: biodiesel, injection system, Diesel, fuel delivery, injection rate meter

\section{Analiza porównawcza dwóch systemów wtryskowych zasilanych biopaliwem}

W artykule przedstawiono wyniki badań wykonanych na dwóch rodzajach systemów wtryskowych z wykorzystaniem paliw alternatywnych. Paliwo alternatywne (B100) pozyskano z przetworzonego oleju roślinnego (zebranego z restauracji typu McDonalds), wykorzystujac podstawowe procesy chemiczne, paliwo konwencjonalne (ON) w badaniach miato charakter porównawczy. Badania wykonano na dwóch rodzajach pomp wtryskowych: RO-PES4A90D410RS2240 (romanian) oraz Boscha (PES5MW55/320/RS/120403), z szyna wysokiego ciśnienia oraz wtryskiwaczami. Uktad wtryskowy zamontowano w systemie MIRKOZ, który składa się z przetworników ciśnienia, przetwornika mierzacego prędkość obrotowa oraz systemu wtryskowego Boscha. Badania odbywaty się przy różnych prędkościach obrotowych watu pompy wtryskowej. Analizie poddano takie parametry, jak: przepływ paliwa, czas trwania wtrysku, czas rozchodzenia się fali ciśnienia, maksymalne ciśnienie wtrysku itp. W przypadku zasilania obydwóch układów wtryskowych paliwem typu biodiesel nastapit wzrost: strumienia objętości paliwa wyplywającego z otworów rozpylaczy, czasu trwania wtrysku oraz maksymalnego ciśnienia wtrysku, natomiast takie parametry, jak: średnia prędkość wtrysku oraz czas rozchodzenia się fali ciśnienia zmniejszyly się.

Key words: biodiesel, system wtryskowy, olej napędowy, szybkość wtrysku paliwa

\section{Introduction}

Vegetable oils and animal fats are a renewable and potentially inexhaustible source of energy, with energy content close to Diesel fuel. Due to their poor physical properties (high viscosity, high pour point), these fuels are unsuited to be used in Diesel engines. These properties can be improved by transesterification; when using methyl alcohol, methyl esters are the final product.

According to Directive 2003/30 EC of the European Parliament and Council [14], the term Biodiesel is used for any methyl ester produced from vegetable or animal oil, of Diesel quality.

It is agreed that a proportion of $2 . .5 \%$ methyl ester in Diesel fuel does not involve any changes in the construction of the engine's fuelling system and this type of Biodiesel blends can be burned directly in unmodified Diesel engines [5].

Cooking oils, used for frying food, have a limited life in food production due to their contamination with material from food and due to fatty acids formation; waste cooking oil can be seen as a "near to waste" by-product of food

\section{Wstęp}

Oleje roślinne oraz thuszcz pochodzenia zwierzęcego są odnawialnymi i potencjalnie niewyczerpalnymi źródłami energii, zbliżonymi zawartością „energii” do konwencjonalnego paliwa, jakim jest olej napędowy. Z powodu niskich właściwości fizycznych (duża lepkość, wysoka temperatura płynięcia) paliwa te są niedopasowane do silników o zapłonie samoczynnym. Niekorzystne parametry chemiczne i fizyczne można polepszyć dzięki procesowi transestryfikacji, w którym finalnym produktem będzie alkohol metylowy oraz estry.

Zgodnie z dyrektywą 2003/30 EC Parlamentu Europejskiego [14] określenie biodiesel używa się w odniesieniu do wszystkich estrów metylowych produkowanych z olejów roślinnych oraz thuszczów zwierzęcych z jakością oleju napędowego.

Istnieje pogląd, iż wprowadzenie dodatku $2-5 \%$ estrów metylowych do oleju napędowego nie wymusi zmian w istniejących systemach wtryskowych silników o zapłonie samoczynnym, przystosowanych do spalania paliwa konwencjonalnego [5]. 
production industry. As a result, the use of waste cooking oil instead of virgin oil in order to produce Biodiesel is an effective way to reduce the raw material cost and helps to solve the problem of waste oil disposal. These vegetable oils contain some degradation products of vegetable oils and foreign material. However, analyses of used vegetable oils claimed that the differences between used and unused fats are not very great and in most cases simple heating and removal by filtration of solid particles makes the oil appropriate for subsequent transesterification [6].

Injection characteristics have a significant effect over the engine working process. For the same injection timing, ignition delay and cyclic fuel delivery, an increased injection duration (or decreased average injection rate) leads to the decrease of the peak combustion pressure; the shape of the engine's working cycle diagram is also affected [2].

\section{Material and method}

The material used for the vegetable oil methylester (VOME) production was waste cooking oil collected from a local branch of the McDonalds' restaurants [7].

The main physical properties of the Biodiesel type fuel (BTF) are summarized in Tab. 1.

Two injection equipments were tested:

- injection pump type PES 5MW 55/320/RS 120403

(Bosch; plunger bore: $5.5 \mathrm{~mm}$ )

- injection pump type RO-PES4A90D410RS2240 (plunger bore: $9 \mathrm{~mm}$ )

- RO-KCA30S16 injectors with RO-DNOSD21 nozzles, opening at $13 \mathrm{MPa}$.

The injection equipment was tested on a MIRKOZ (Hungary) test rig, using a Bosch injection rate meter and an IAN 101 oscilloscope.

The tests were developed at different pump speeds (500 to 1200 $\mathrm{rev} / \mathrm{min}$ ) and displacements of the injection pump control rod; for the both injection pumps the speed governor was disabled.

During the tests Diesel fuel and Biodiesel-Diesel fuel mixture (50\% Biodiesel - B50) were used.

The following injection characteristics were investigated:

- cyclic fuel delivery

- injection duration
Oleje używane do smażenia pożywienia cechują się ograniczonym czasem wykorzystania; czynnikami, które mają duży wpływ na to są zanieczyszczenia oraz tworzenie się kwasów tłuszczowych. Z tego powodu dobry wydaje się pomysł produkcji paliwa typu biodiesel ze zużytych olejów; dzięki temu uda się obniżyć koszty produkcji paliwa oraz rozwiązać problem recyklingu.

Analiza przeprowadzona na zużytych oraz nowych olejach roślinnych wykazała, że różnice miedzy tymi olejami są bardzo małe. W wielu przypadkach, aby przeprowadzić końcowy proces, jakim jest transestryfikacja należy tylko podgrzać oraz przefiltrować zużyty olej [6].

Proces wtrysku paliwa do komory spalania ma ogromny wpływ na pracę silnika spalinowego. Zmiana parametrów, takich jak: czas trwania wtrysku, czas rozchodzenia się fali ciśnienia, maksymalne ciśnienie wtrysku prowadzi do zmniejszenia maksymalnego ciśnienia $\mathrm{w}$ cylindrze, co zmienia w znaczący sposób przebieg ciśnienia w cylindrze (wykres indykatorowy) [2].

\section{Material oraz metody badań}

Materiałem użytym do badań był zużyty olej roślinny metyloester (VOME), który pochodził z restauracji typu McDonalds [7].

Główne parametry fizyczne paliwa biodiesel (BTF) przedstawiono w tab. 1.

Przebadano dwa systemy wtryskowe:

- pompa wtryskowa PES 5MW 55/320/RS 120403 (Bosch; średnica tłoka 5,5 mm)

- pompa wtryskowa RO-PES4A90D410RS2240 (średnica tłoka $9 \mathrm{~mm}$ )

- RO-KCA30S16 wtryskiwacze z RO-DNOSD21 rozpylaczami, ciśnienie otwarcia wtryskiwacza $13 \mathrm{MPa}$.

Układ wtryskowy zamontowano w systemie MIRKOZ, który składa się z przetworników ciśnienia, przetwornika mierzącego prędkość obrotową oraz systemu wtryskowego Boscha.

Badania odbywały się przy różnych prędkościach obrotowych wału pompy wtryskowej (500-1200 obr/min). Podczas badań używano mieszaniny paliw 50/50 (50\% biodiesel $\mathrm{B} 50)$. Analizie poddano takie parametry, jak:

- przepływ paliwa

- czas trwania wtrysku

Table 1. Physical characteristics of the fuels

Tabela 1. Parametry fizyczne paliw

\begin{tabular}{|c|c|c|c|c|c|}
\hline \multirow{2}{*}{ Item } & \multirow{2}{*}{$\begin{array}{l}\text { Test } \operatorname{method} / \text { meto- } \\
\text { da badawcza }\end{array}$} & \multicolumn{4}{|c|}{ Fuel/paliwo } \\
\hline & & Diesel/ON & $\begin{array}{l}\text { Used cooking oil/ } \\
\text { zużyty olej roślinny }\end{array}$ & B100 & B50 \\
\hline Density at/gęstość $w 15^{\circ} \mathrm{C}\left[\mathrm{g} / \mathrm{cm}^{3}\right]$ & EN ISO 3675 & 0.8393 & 0.891 & 0.857 & 0.851 \\
\hline Viscosity at/lepkość w $40^{\circ} \mathrm{C}\left[\mathrm{mm}^{2} / \mathrm{s}\right]$ & EN ISO 3104 & 4.9 & 34.0 & 5.7 & 5.2 \\
\hline Acid value/liczba kwasowa $[\mathrm{mg} \mathrm{KOH} / \mathrm{g}]$ & ASTM D664 & 0.089 & 2.67 & 0.92 & 0.42 \\
\hline Ash content/ilość popiołu [\%] & SR ISO 6245:1995 & 0.085 & 0.075 & 0.038 & 0.016 \\
\hline Flash point/temp. zapłonu $\left[{ }^{\circ} \mathrm{C}\right]$ & ASTM D93 & 69 & 115 & 110 & 82 \\
\hline $\mathrm{Cu}$ strip corrosion/Cu korozja & EN ISO 2160 & $1 b$ & $2 \mathrm{e}$ & $2 \mathrm{a}$ & $1 b$ \\
\hline $\begin{array}{l}\text { Surface tension/napięcie powierzchniowe } \\
{[\mathrm{N} / \mathrm{m}]}\end{array}$ & - & 0.0281 & 0.0336 & 0.0296 & 0.0290 \\
\hline
\end{tabular}


- pressure wave propagation time

- average injection rate

- peak injection pressure.

The average injection rate was defined as the ratio between the cyclic fuel delivery and the injection duration.

\section{Research results}

\subsection{Cyclic fuel delivery}

Figure 1 presents some experimental results referring to the cyclic fuel delivery of the two injection pumps, at different speeds. The cyclic fuel delivery increases with pump speed and control rod displacement, but is affected by the type of fuel used.

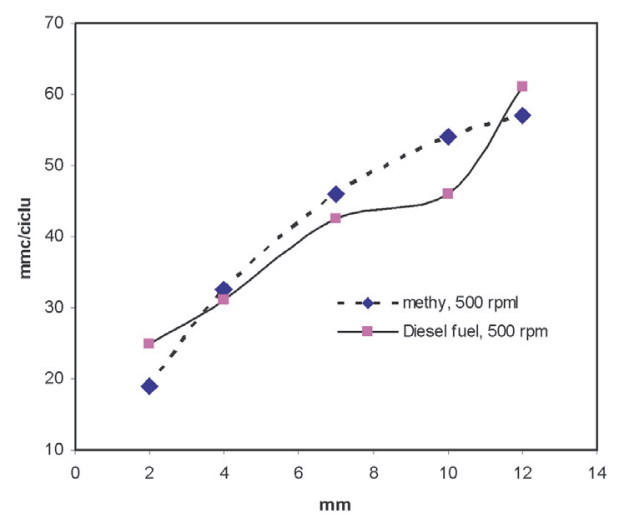

a)

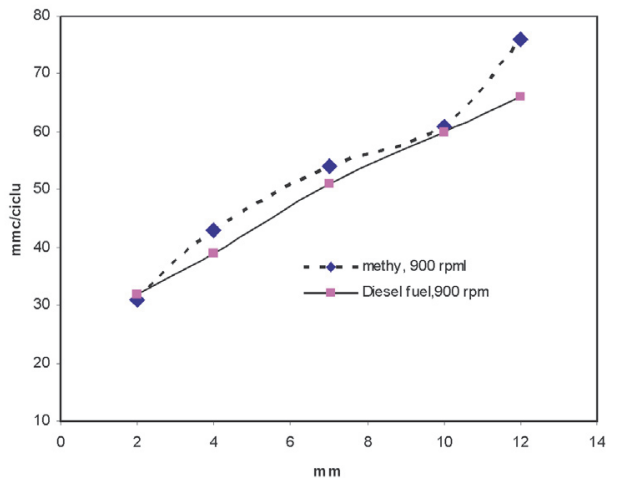

c)
- czas rozchodzenia się fali ciśnienia

- średnia prędkość wtrysku

- maksymalne ciśnienie wtrysku.

Średnią prędkość wtrysku zdefiniowano jako stosunek wypływu objętościowego paliwa z otworów rozpylacza do czasu trwania wtrysku.

\section{Wyniki badań}

\subsection{Dawka paliwa przypadająca na cykl}

Wyniki badań dawki paliwa przypadającej na cykl przy użyciu 2 różnych pomp wtryskowych oraz dla różnych prędkości obrotowych przedstawiono na rys. 1. Dawka

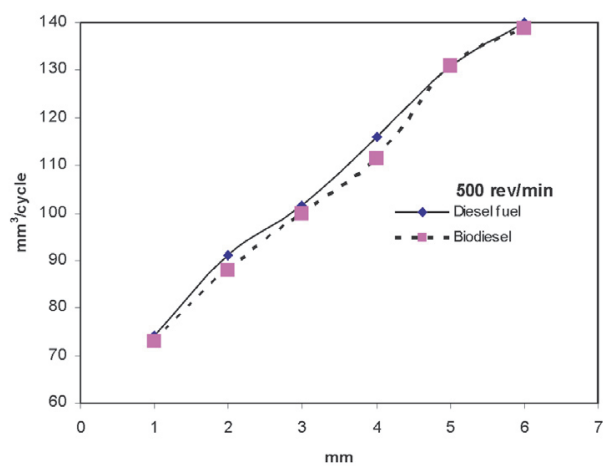

b)

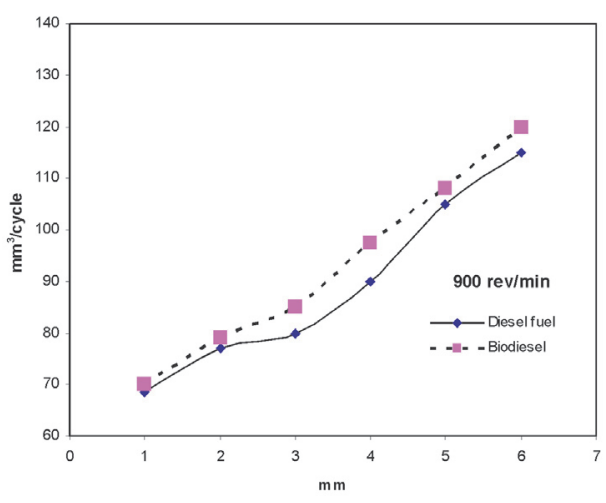

d)

Fig. 1. Cyclic fuel delivery: a) Bosch injection pump, $500 \mathrm{rev} / \mathrm{min}$, b) RO-PES injection pump, $500 \mathrm{rev} / \mathrm{min}$, c) Bosch injection pump, $900 \mathrm{rev} / \mathrm{min}$, d) RO-PES injection pump, $900 \mathrm{rev} / \mathrm{min}$

Rys. 1. Przeptyw paliwa: a) pompa wtryskowa Boscha, $500 \mathrm{obr} / \mathrm{min}$, b) pompa wtryskowa RO-PES, 500 obr/min, c) pompa wtryskowa Boscha, 900 obr/min, d) pompa wtryskowa RO-PES, $900 \mathrm{obr} / \mathrm{min}$

There is a clear tendency towards the increase of the amount of delivered fuel when B50 is used. For the Bosch injection pump this behavior is noticeable even at low pump speeds (500 rev/min), while for the RO-PES injection pump the amount of B50 delivered at $500 \mathrm{rev} / \mathrm{min}$ is lower compared to the one of Diesel fuel. As pump speed increases, both the RO-PES and the Bosch injection pump deliver higher amounts of fuel when B50 is used (Figs 1c and 1d).

\subsection{Injection duration}

The results concerning the injection duration are shown in Fig. 2. As fuel delivery increases with the displacement of the injection pump control rod, the injection duration also paliwa przypadająca na cykl uzależniona jest od prędkości obrotowej wału pompy wtryskowej, ustawienia nastawnika oraz użytego paliwa.

Wyraźnie uwidacznia się tendencja do zwiększania dawki paliwa przypadającej na cykl, kiedy pompa wtryskowa tłoczy paliwo B50. W przypadku pompy wtryskowej Boscha tendencja ta widoczna jest już dla prędkości $500 \mathrm{obr} / \mathrm{min}$, natomiast dla pompy wtryskowej RO-PES i paliwa B50 wydatek przy tej samej prędkości jest zdecydowanie mniejszy w porównaniu z wynikami badania paliwa konwencjonalnego ON. Zwiększenie prędkości obrotowej wału obu pomp powoduje zwiększenie dawki paliwa przypadającej na cykl dla paliwa B50 (rys. 1c i 1d). 
increases. For the RO-PES injection pump the use of the B50 fuels leads to an increased injection duration (with $2.5 \ldots 18 \%$ at $500 \mathrm{rev} / \mathrm{min}$ and respectively with $5.6 \ldots 11 \%$ at 900 $\mathrm{rev} / \mathrm{min}$ ), compared to Diesel fuel (Fig. $2 \mathrm{~b}$ and $2 \mathrm{~d}$ ), due to the higher amount of injected fuel provided by this pump.

At low speeds, the injection duration for the Bosch injection pump decreases when fueled with B50 (Fig. 2a); at 900 $\mathrm{rev} / \mathrm{min}$ the values recorded for Biodiesel are very close to the ones registered for Diesel fuel (Fig. 2c) and only for the $1200 \mathrm{rev} / \mathrm{min}$ regime the injection duration is increased with $9.7 . .19 \%$ when B50 is used as fuel.

The experimental results concerning the time the pressure wave needs to travel between the injection pump outlet and the injector inlet are shown in Fig. 3. For the both injection equipments the pressure wave propagation time is shorter when Biodiesel fuel blend is used; this finding, also reported by other authors $[11,12]$, seems to be the effect of the higher viscosity and isentropic bulk modulus.

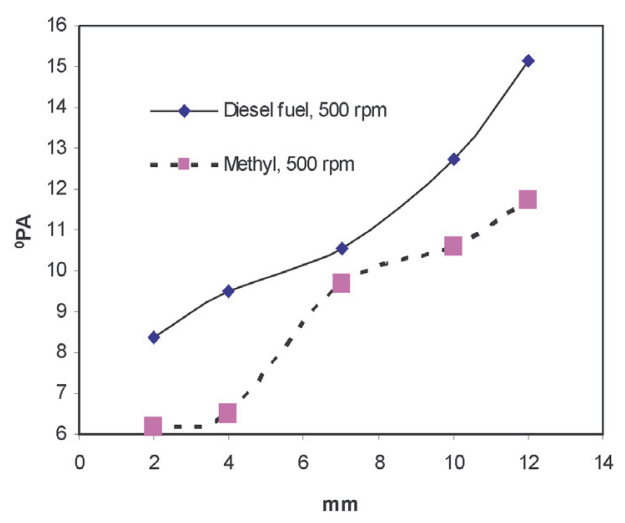

a)

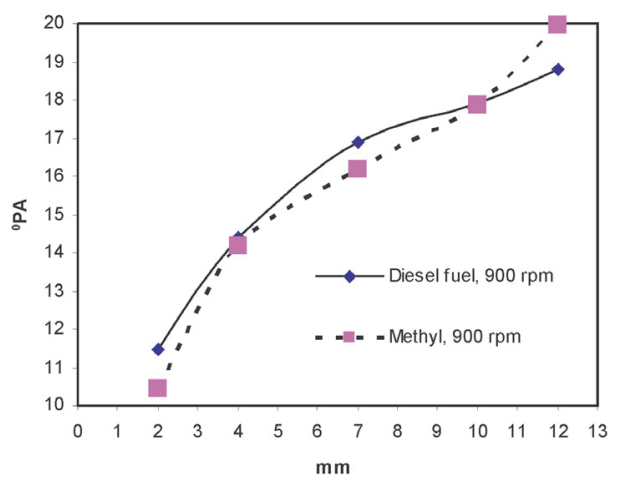

c)

\subsection{Czas trwania wtrysku paliwa}

Wyniki badań dotyczące czasu trwania wtrysku paliwa przedstawiono na rys. 2. Wzrost ilości paliwa wywołany zmianą nastawnika pompy wtryskowej powoduje zwiększenie czasu trwania wtrysku. Badania na pompie RO-PES przy użyciu paliwa B50 wskazują wzrost czasu trwania wtrysku (z 2,5 do $18 \%$ przy $500 \mathrm{obr} / \mathrm{min}$ oraz 5,6 do $11 \%$ dla prędkości obrotowej $900 \mathrm{obr} / \mathrm{min}$ ), w porównaniu do użytego oleju napędowego (rys. 2b i 2d), z powodu większej ilości wtryskiwanego paliwa.

Dla niskich prędkości obrotowych i pompy Boscha przy paliwie B50 czas trwania wtrysku zmniejsza się (rys. 2a). Dla prędkości obrotowej 900 obr/min zarejestrowana wartość dla paliwa biodiesel jest bardzo zbliżona do wartości paliwa konwencjonalnego - ON (rys. 2c) i tylko dla prędkości obrotowej 1200 obr/min czas wtrysku dla biodiesla wzrasta z 9,7 do $19 \%$.

Na rysunku 3 przedstawiono wyniki badań przemieszczającej się fali ciśnienia między pompą wtryskową a wtry-

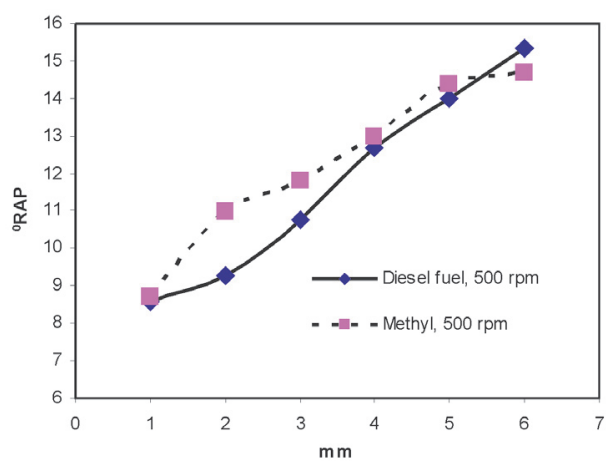

b)

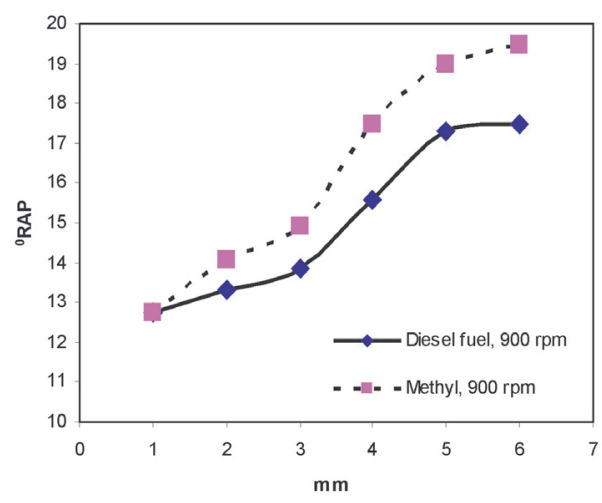

d)

Fig. 2. Injection duration: a) Bosch injection pump, $500 \mathrm{rev} / \mathrm{min}$, b) RO-PES injection pump, $500 \mathrm{rev} / \mathrm{min}$, c) Bosch injection pump, $900 \mathrm{rev} / \mathrm{min}$, d) RO-PES injection pump, $900 \mathrm{rev} / \mathrm{min}$

Rys. 2. Czas wtrysku: a) pompa wtryskowa Boscha, $500 \mathrm{obr} / \mathrm{min}$, b) pompa wtryskowa RO-PES, $500 \mathrm{obr} / \mathrm{min}$, c) pompa wtryskowa Boscha, $900 \mathrm{obr} / \mathrm{min}$, d) pompa wtryskowa RO-PES, $900 \mathrm{obr} / \mathrm{min}$

The propagation time has decreased with $0.4 \ldots 0.8^{\circ} \mathrm{PA}$ when the B50 was used instead of Diesel fuel. It should be mentioned that a lower pressure wave propagation time is equivalent with an earlier start of injection (injection timing advanced by $0.8 \ldots 1.6^{\circ} \mathrm{CA}$ ) and may result in higher levels of $\mathrm{NO}_{\mathrm{x}}$ emissions $[3,9,10]$. As Biodiesel type fuels were skiwaczem. Dla obu analizowanych systemów wtryskowych przy zasilaniu paliwem typu biodiesel czas rozchodzenia się fali ciśnienia zmniejszył się; efekt ten można wytłumaczyć większą lepkością oraz modułem Helmholtza - izentropowego współczynnika sprężystości objętościowej, który przybiera mniejszą wartość dla oleju napędowego [11, 12]. 
reported to have a shorter ignition delay compared to Diesel fuel $[1,8]$, the cumulative effect of the lower propagation time and shorter ignition delay is expected to induce an

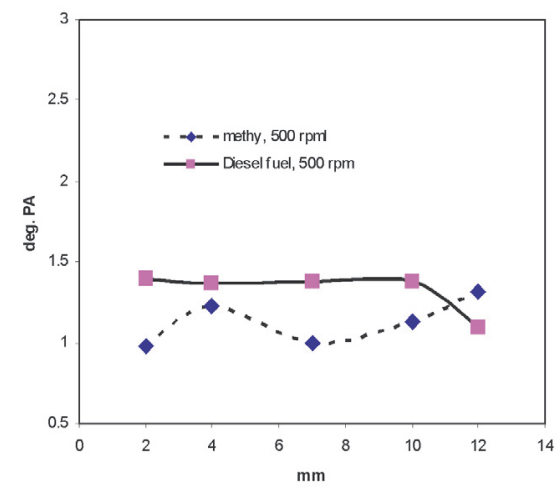

a)

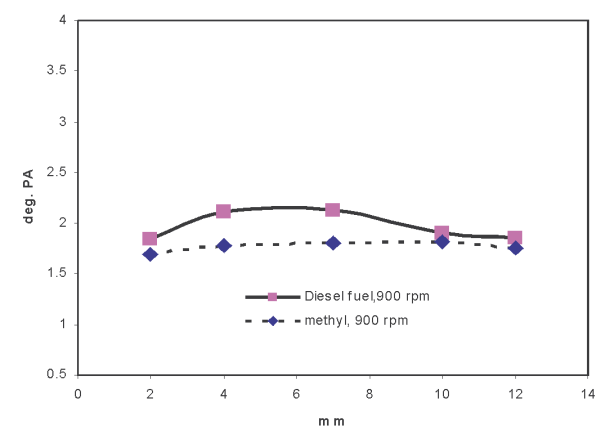

c)
Czas rozchodzenia się wtrysku zmniejszył się z 0,4 do $0,8^{\circ} \mathrm{OWP}$ dla paliwa $\mathrm{B} 50 \mathrm{w}$ porównaniu do oleju napędowego. Niskie ciśnienie w układzie wtryskowym powoduje, że

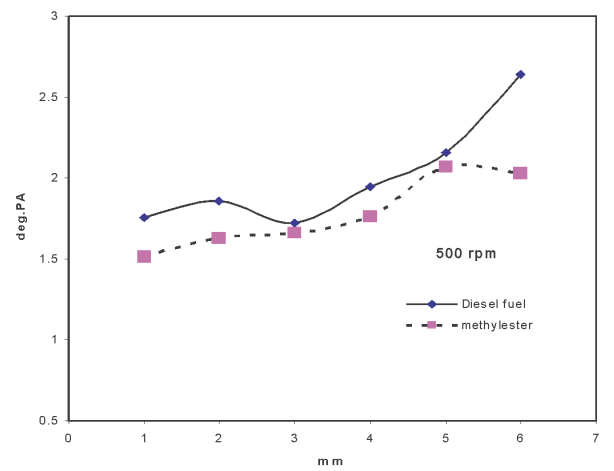

b)

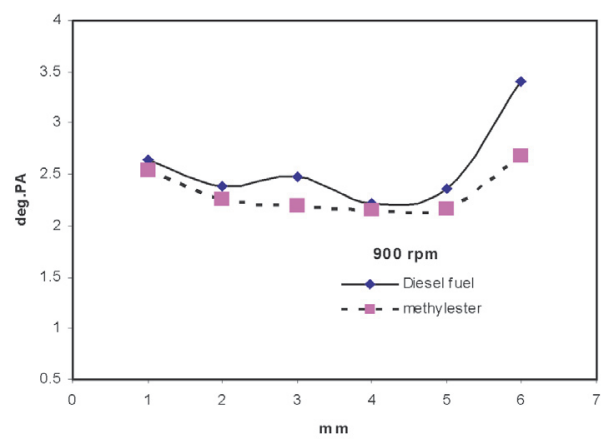

d)

Fig. 3. Pressure wave propagation time: a) Bosch injection pump, $500 \mathrm{rev} / \mathrm{min}, \mathrm{b})$ RO-PES injection pump, $500 \mathrm{rev} / \mathrm{min}$, c) Bosch injection pump, $900 \mathrm{rev} / \mathrm{min}, \mathrm{d}) \mathrm{RO}-\mathrm{PES}$ injection pump, $900 \mathrm{rev} / \mathrm{min}$

Rys. 3. Czas rozchodzenia się fali ciśnienia: a) pompa wtryskowa Boscha, 500 obr/min,b) pompa wtryskowa RO-PES, 500 obr/min, c) pompa wtryskowa Boscha, 900 obr/min, d) pompa wtryskowa RO-PES, 900 obr/min

overall advance of the start of combustion that could reach $1.8 \ldots 2^{\circ} \mathrm{CA}$. As a result the $\mathrm{NO}_{\mathrm{x}}$ emissions will be significantly affected, unless adjustments of the injection timing are made.

\subsection{Average injection rate}

The higher cyclic fuel delivery of the RO-PES pump has conducted to the achievement of higher average injection rates compared to the Bosch injection pump (Fig. 4); increasing the pump speed has led to lower average injection rates because of the higher injection duration.

For the Bosch injection pump the average injection rates achieved by the B50 fuel are higher then the ones recorded for Diesel fuel (Fig. 4a and 4c); the most significant differences are recorded at low pump speeds $(17 \ldots 53 \%$ increase at $500 \mathrm{rev} / \mathrm{min}$, respectively $8 \ldots 12 \%$ increase at 900 $\mathrm{rev} / \mathrm{min}$ ); this behavior shows that the lower injection duration recorded for B50 has a more significant effect then the higher cyclic fuel delivery.

The RO-PES injection pump recorded lower average injection rates for B50 compared to Diesel fuel (6...18\% decrease at $500 \mathrm{rev} / \mathrm{min}$ and $0 \ldots 6.4 \%$ decrease at 900 $\mathrm{rev} / \mathrm{min}$ ); the higher injection duration obtained for the Biodiesel fuel explains this behavior. początek wtrysku paliwa występuje szybciej (czas wtrysku wzrósł z 0,8 do $1,6^{\circ} \mathrm{OWK}$ ) i może zwiększyć emisję $\mathrm{NO}_{\mathrm{x}}$ $[3,9,10]$.

Paliwo typu biodiesel charakteryzuje się krótszą zwłoką samozapłonu w porównaniu do oleju napędowego $[1,8]$, zestawienie tych dwóch efektów: krótszą zwłoką samozapłonu i krótszym czasem rozprzestrzeniania się powoduje korzyść z tytułu osiągnięcia zapoczątkowania spalania w 1,8 do $2^{\circ}$ obrotu wału korbowego. W wyniku tych zmian może ulec zmianie także emisja $\mathrm{NO}_{x}$ wtedy, gdy nie będzie zmieniony czas wtrysku paliwa.

\section{3. Średnia prędkość wtrysku paliwa}

Wyższy stopień pompowania paliwa dla pompy RO-PES spowodował osiągniecie wyższej średniej prędkości wtrysku w porównaniu do pompy wtryskowej typu Bosch (rys. 4). Zwiększenie prędkości pompowania prowadzi do zmniejszenia średniej prędkości wtrysku paliwa, co spowodowane jest dłuższym czasem trwania wtrysku.

Badania wykonane na pompie wtryskowej Boscha wykazały, że średnia prędkość wtrysku paliwa jest większa dla paliwa typu B50 niż dla oleju napędowego (rys. $4 a, c)$. 


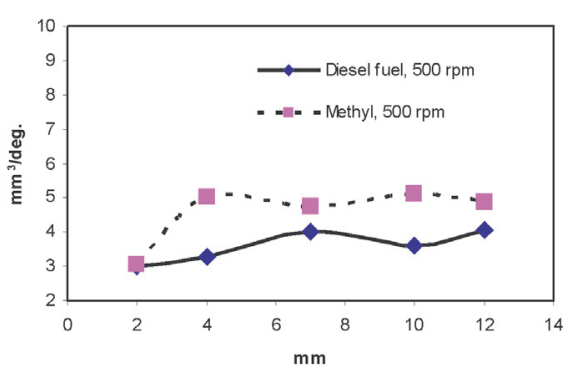

a)

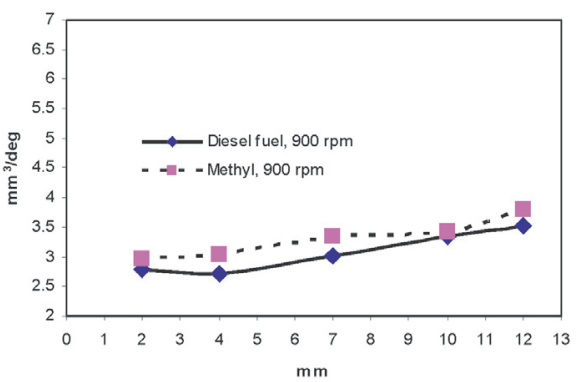

c)]

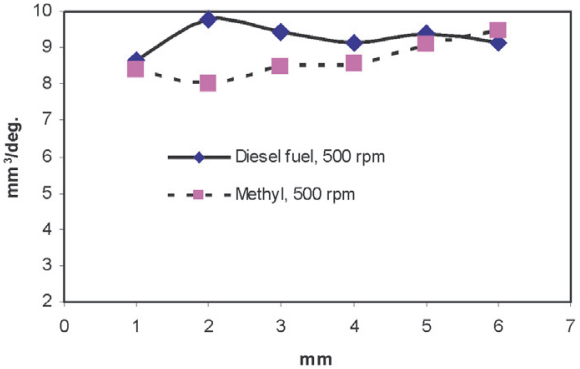

b)

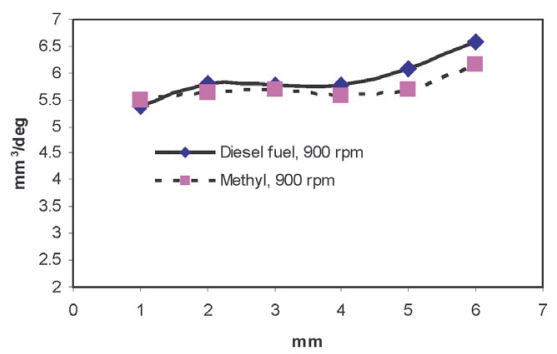

d)

Fig. 4. Average injection rate: a) Bosch injection pump, $500 \mathrm{rev} / \mathrm{min}, \mathrm{b})$ RO-PES injection pump, $500 \mathrm{rev} / \mathrm{min}$, c) Bosch injection pump, $900 \mathrm{rev} / \mathrm{min}$, d) RO-PES injection pump, $900 \mathrm{rev} / \mathrm{min}$

Rys. 4. Średnia prędkość wtrysku paliwa: a) pompa wtryskowa Boscha, 500 obr/min, b) pompa wtryskowa RO-PES, 500 obr/min, c) pompa wtryskowa Boscha, $900 \mathrm{obr} / \mathrm{min}$, d) pompa wtryskowa RO-PES, $900 \mathrm{obr} / \mathrm{min}$

\subsection{Peak injection pressure}

The experiments show that the RO-PES pump achieves higher peak injection pressures then the Bosch pump. From Figure 5 it is obvious that the use of methylester leads to higher injection pressures, due to the higher viscosity of B50. The pressure increased with 1...4 MPa bar for the Bosch injection pump (Fig. 5a and 5c) and with 4...6.5 MPa for the RO-PES injection pump (Fig. 5b and 5d), depending upon pump speed and position of the control rod.

For the RO-PES pump significantly increased peak injection pressures were recorded at low speeds, while for the Bosch pump this behavior was displayed mainly at high speeds.

\section{Discussion}

The use of the B50 Biodiesel blend affects the cyclic fuel delivery increasing the amount of injected fuel; the slightly higher viscosity of Biodiesel diminishes fuel loss through the gap between the piston and pump cylinder, thus increasing the quantity of delivered fuel.

The injection duration decreased when the Bosch injection pump was fueled with B50, but was prolonged for the RO-PES injection pump. This latter behavior could be explained taking into account the fuel delivery correction device mounted on the exhaust valve: due to the higher viscosity of the B50 fuel, higher hydraulic forces are acting upon the valve, thus increasing the lifting height; as a result a larger amount of fuel is needed to compensate the volume dislocated by the correction device and injection duration is increased. For the Bosch injection pump (with smaller plunger bore), the increased bulk modulus of the B50 fuel
Duże zmiany w wartościach zarejestrowano przy dużych prędkościach obrotowych pompy wtryskowej (z 17 do 53\% wzrostu przy $500 \mathrm{obr} / \mathrm{min}$ oraz z 8 do $12 \%$ wzrostu przy 900 obr/min). Wskazuje to, że krótszy czas trwania wtrysku zarejestrowany dla paliwa B50 ma większy wpływ na średnią prędkość wtrysku niż większa dawka paliwa na wtrysk (położenie nastawnika pompy - przyp. tłum.).

Badania wykonane na pompie wtryskowej RO-PES wykazały, że średnia prędkość wtrysku paliwa jest niższa dla paliwa typu B50 niż dla oleju napędowego (z 6 do 18\% zmniejszenie przy $500 \mathrm{obr} / \mathrm{min}$, z 0 do $6,4 \%$ zmniejszenie przy $900 \mathrm{obr} / \mathrm{min})$. Tłumaczy to dłuższy czas trwania wtrysku występujący przy użyciu paliwa typu biodiesel.

\subsection{Maksymalne ciśnienie wtrysku}

Wyniki badań wykazały, że dla pompy wtryskowej RO-PES maksymalne ciśnienie wtrysku jest wyższe niż dla pompy Boscha. Użycie paliwa typu biodiesel powoduje wzrost ciśnienia wtrysku, co jest związane ze zwiększoną lepkością (B50, rys. 5). Ciśnienie zwiększyło się z 1 do 4 MPa dla pompy wtryskowej Boscha (rys. 5a, c) i z 4 do 6,5 MPa dla pompy RO-PES (rys. 5b, d).

Dla pompy wtryskowej RO-PES znacząco zwiększyło się maksymalne ciśnienie wtrysku przy niskich prędkościach obrotowych, w przeciwieństwie do pompy Boscha, w której to samo zjawisko obserwowano przy wysokich prędkościach obrotowych.

\section{Omówienie wyników badań}

Użycie paliwa typu B50 (biopaliwa) zapobiega wzrostowi wtryskiwanego paliwa do komory spalania. Duża lepkość biopaliw zmniejsza straty, jakie mogą występować 
has a more significant effect then the action of the correction device leading to decreased injection duration.

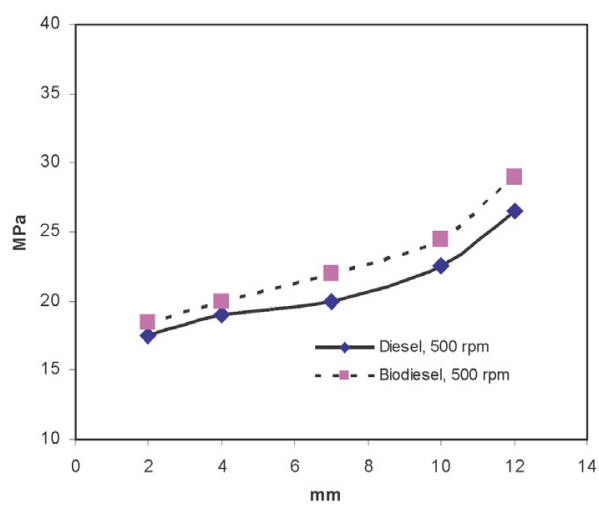

a)

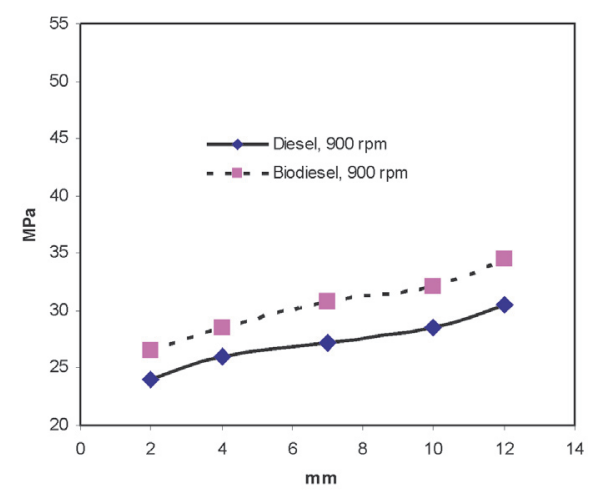

c) pomiędzy tłokiem a cylindrem, co prowadzi do zwiększenia jakości dostarczanego paliwa.

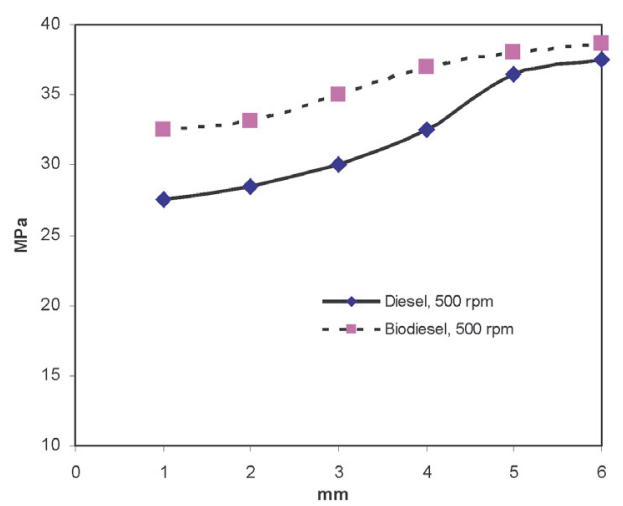

b)

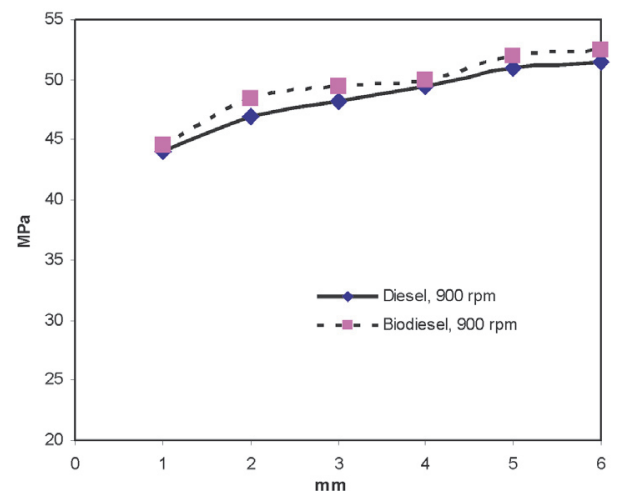

d)

Fig. 5. Peak injection pressure: a) Bosch injection pump, $500 \mathrm{rev} / \mathrm{min}, \mathrm{b})$ RO-PES injection pump, $500 \mathrm{rev} / \mathrm{min}, \mathrm{c}) \mathrm{Bosch}$ injection pump, $900 \mathrm{rev} /$ min, d) RO-PES injection pump, $900 \mathrm{rev} / \mathrm{min}$

Rys. 5. Maksymalne ciśnienie wtrysku: a) pompa wtryskowa Boscha, 500 obr/min, b) pompa wtryskowa RO-PES, 500 obr/min, c) pompa wtryskowa Boscha, $900 \mathrm{obr} / \mathrm{min}$, d) pompa wtryskowa RO-PES, $900 \mathrm{obr} / \mathrm{min}$

The average injection rate is higher for the RO-PES injection pump because it has to deliver a higher amount of fuel, while the injection duration is roughly the same time for the both injection systems. The lower injection duration recorded for the Bosch injection pump led to higher average injection rates for this injection pump compared to the RO-PES pump.

The higher viscosity and isentropic bulk modulus of the B50 fuel lead to shorter delays in the pressure wave transmission time and to higher peak injection pressures. The shorter propagation time for the pressure wave and the shorter ignition delay which is usually associated with the Biodiesel type fuels are expected to induce an earlier start of the combustion process. In the meantime, higher peak injection pressures are expected to counteract the negative effect of the viscosity over the fuel spray characteristics. For the Bosch injection pump the higher average injection rates could also improve the fuel spray characteristics.

\section{Conclusions}

1. A Biodiesel type fuel ( $50 \%$ methyl ester $+50 \%$ Diesel fuel - B50) was used in order to fuel two injection systems.

2. The two injection systems were equipped with different size in line injection pumps.
Czas wtrysku paliwa przy użyciu pompy Boscha zmniejsza się, gdy badania są wykonywane przy użyciu paliwa B50, a zwiększa się przy stosowaniu pompy wtryskowej RO-PES. Można to wythumaczyć, uwzględniając korekcję podawania paliwa. Z powodu większej lepkości i powstawania dużej siły hydraulicznej dla B50 większa ilość paliwa jest wymagana do skompensowania przemieszczania się objętości korekcja dawki.

Średnia prędkość wtrysku dla pompy RO-PES jest większa, ponieważ dostarcza większą ilość paliwa, podczas gdy czas trwania wtrysku w obu systemach jest porównywalny. Krótszy czas trwania wtrysku zarejestrowany dla pompy typu Bosch powodował zwiększenie średniej prędkości wtrysku w porównaniu z pompą wtryskową typu RO-PES.

Większa lepkość oraz izentropowy współczynnik sprężystości objętościowej paliwa B50 skracają opóźnienie przepływu fal ciśnienia i podwyższają maksymalne ciśnienia wtrysku. Oczekuje się, że krótszy czas rozchodzenia się fal ciśnienia oraz krótszy czas opóźnienia zapłonu przyspieszą procesy spalania. Jednocześnie wyższe maksymalne ciśnienia wtrysku mają przeciwdziałać negatywnemu wpływowi lepkości paliwa na charakterystykę strugi paliwa. W przypadku pompy wtryskowej Boscha, większa średnia prędkość wtrysku może także poprawić charakterystykę strugi paliwa. 
3. The injection characteristics (cyclic fuel delivery, injection duration, average injection rate, pressure wave propagation time and peak injection pressure) were measured.

4. Injection characteristics were affected by the use of the B50 fuel, due to its higher viscosity and isentropic bulk modulus.

5. The fuel delivery correction devices mounted on the RO-PES pump exhaust valve produced longer injections compared to the Bosch injection pump; the average injection rate was consequently affected.

Artykut recenzowany

\section{Wnioski}

1. Do zasilania dwóch systemów wtrysku użyto biopaliwo typu B50 (50\% estru metylowego $+50 \%$ oleju napędowego).

2. Obydwa systemy wtrysku były wyposażone w różnej wielkości pompy wtrysku.

3. Wyznaczono charakterystykę wtrysku (częstość podawania dawki paliwa, czas wtrysku, średnią prędkość wtrysku, czas rozchodzenia się fal ciśnienia i maksymalne ciśnienie wtrysku).

4. Na charakterystykę wtrysku wpłynęło zastosowanie paliwa typu B50 charakteryzujące się większą lepkością i izentropowym współczynnikiem sprężystości objętościowej paliwa.

5. Urządzenie do korekcji dawki paliwa zamontowane w pompie wtryskowej RO-PES wydłużało czas wtrysku w porównaniu do pompy wtryskowej Boscha, a to w konsekwencji wpłynęło na średnią prędkość wtrysku paliwa.

\section{Nomenclature/oznaczenia}

B100 pure methyl ester/czysty ester metylowy

B50 $50 \%$ methylester $+50 \%$ Diesel fuel $/ 50 \%$ biopaliwo $+50 \%$ olej napędowy
CA crankshaft rotation angle/kat obrotu watu

PA injection pump shaft rotation angle/kąt obrotu watu pompy wtryskowej

VOME vegetable oil methylester/olej roślinny metyloester

\section{Bibliography/Literatura}

[1] Canakci M., Van Gerpen J.H.: Comparison of Engine Performance and Emissions for Petroleum Diesel Fuel. Yellow Grease Biodiesel, and Soybean Oil Biodiesel. Presented as Paper No. 016050 at the 2001 ASAE Annual International Meeting, Sacramento, California, USA, July 30-August 1, 2001.

[2] Heywood J.B.: Internal Combustion Engine Fundamentals. McGraw-Hill Book Co., New York 1988.

[3] Monyem A, Van Gerpen J.H., Canakci M.: The effect of timing and oxidation on emissions from biodiesel fueled engines. Transactions of ASAE, 44(1), 2001, pp. 35-42.

[4] Prankl H., Wörgetter M.: Standardization of Biodiesel. Sectorial Report "Biodiesel" of NTB-nett Phase II. Report of the Federal Institute of Agricultural Engineering, Wieselburg, Austria 1997.

[5] Prankl H., Wörgetter M.: The introduction of biodiesel as blending component to Diesel fuel in Austria. Final Report of NTB-nett Phase IV. Report of the Federal Institute of Agricultural Engineering, Wieselburg, Austria 2000.

[6] Rice B., Frohlich A., Leonard R.: Bio-diesel Production based on Waste Cooking Oil: Promotion of the Establishment of an Industry in Ireland. ALTENER Contract no. XVII/4.1030/ AL/77/95/IRL. Agriculture and Food Development Authority, Ireland 1997.

[7] Rosca R., Rakosi E., Niculaua M.: Biodiesel for I.C. Diesel Engines from Waste Cooking Oil. Proceedings of the 33rd International Symposium on Agricultural Engineering, Opatija, Croatia 2005, pp. 47-54.

Mr. Rosca Radu, DEng. - Asssoc. professor in the Faculty of Horticulture at the University of Agricultural Sciences Iasi, Romania.

Dr inż. Rosca Radu - profesor na Wydziale Ogrodnictwa Uniwersytetu Nauk Rolniczych Iasi, Rumunia.

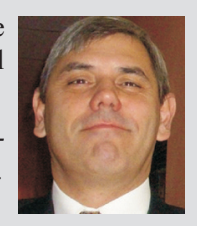

[8] Ryan T. W.: Correlation of physical and chemical ignition delay to cetane number. SAE Technical Paper Series 852103, 1985.

[9] Senatore A., Cardone M.: A Comparative Analysis of Combustion Process in D.I. Diesel Engine Fueled with Biodiesel and Diesel Fuel. SAE Technical Papers Series 2000-01-0691, 2000.

[10] Tat M.E.: Investigation of oxides of nitrogen emissions from biodiesel-fueled engines. A dissertation submitted to the graduate faculty in partial fulfillment of the requirements for the degree of doctor of philosophy, Iowa State University 2003.

[11] Tat M.E., Van Gerpen J.H.: Measurement of biodiesel speed of sound and its impact on injection timing - final report. NREL/ SR-510-31462, 2003.

[12] Yamane K., Ueta A., Shimamoto Y.: Influence of physical and chemical properties of biodiesel fuel on injection, combustion and exhaust emission characteristics in a DI-CI engine. Proceedings of the 5th International Symposium COMODIA, July 1-4, Nagoya 2001, pp. 402-409.

[13] Zhang Y., Dube M.A., McLean D.D., Kates M.: Biodiesel production from waste cooking oil: 1 . Process design and technological assessment. Bioresource Technology, 89, 2003, pp. 1-16.

[14] Directive 2003/30/EC of the European Parliament and of the Council. Official Journal of the European Union L123, 2003, pp. 42-46.

Mr. Rakosi Edward, DEng. - Professor in the Faculty of Mechanical Engineering at Technical University Iasi, Romania.

Dr inż. Rakosi Edward-profesor na Wydziale Mechanicznym Uniwersytetu Technicznego Iasi, Rumunia.

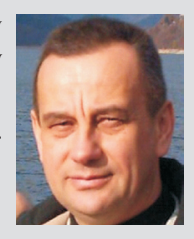

